\title{
Exploring How Nigerian Banks Regulators Enforce Compliance with the Code of Corporate Governance
}

\author{
Tayo-Tiwo, Aderonke, \\ Walden University, Minnesota
}

Doi:10.19044/esj.2020.v16n4p14 ～URL:http://dx.doi.org/10.19044/esj.2020.v16n4p14

\begin{abstract}
Frequent bank failures in Nigeria, resulting in enormous losses of investments and jobs, have raised questions about the banks' compliance with the code of corporate governance. This single exploratory qualitative case study focused on the regulators of banks in Nigeria, the CBN, to find out the problems they may be encountering. Purposeful sampling was used to select 25 participants, and data were collected through Semistructured interviews. The agency theory served as the conceptual framework. Findings showed that the $\mathrm{CBN}$ had put measures in place to ensure full compliance. Some of which included the installation of robust IT architecture, the recruitment of highly skilled IT personnel, in-depth monthly e-examinations of the banks, application of steep penalties, enforcement of the omnibus clause, and continuous staff training. Findings revealed in this paper show that the Central Bank of Nigeria had implemented several measures that would forestall future bank failures among Nigerian banks.
\end{abstract}

Keywords: Compliance, Code of Corporate Governance, Regulators, and Nigerian Banks

\section{Introduction}

The issue of bank failures and liquidation has been a persistent problem in Nigeria since the emergence of the banks in 1892. Most of the pioneer banks failed because of mismanagement, shoddy reporting, and uncoordinated practices among the staff and the directors of the banks. The advent of the regulatory agency, the Central Bank of Nigeria, CBN, in 1959 led to standardization in the banking sector (Omojiade, 2016).

There was an improvement in the financial activities in the banking sector because the regulators paid more attention to the efficient running of organizations and highlighted the duties of the board members to the banks. The Nigerian banking system witnessed tremendous growth post until 2006 when issues of distress started to occur. The CBN introduced the code of 
corporate governance immediately to instill financial discipline in the system (Umanholen, 2015).

As at that time, the paid-up capital of banks was $\$ 25 \mathrm{~m}$, which was quite low such that the inadequately capitalized Bank collapsed and folded up because of systemic shocks (Afolabi \& Dare, 2015). Mergers and acquisitions, resulting in the consolidation of banks, started in 2006, and the minimum paidup capital of banks increased to $\$ 125$ million (Nwagbara \& Ugorji, 2015). As a result, the number of banks and discount houses operating in the country reduced to 25 from 87 (Ozili \& Udiale, 2017).

The 2008 global economic crisis harmed the Nigerian banks, and it led to yet another period of a near-collapse of the Nigerian economy. The regulators, the $\mathrm{CBN}$, quickly intervened by injecting over $\$ 4.2$ billion into the economy to forestall a systemic collapse (Umanholen, 2015). As a result, the regulators conducted another round of an in-depth appraisal of the activities of the banks. The amended code of corporate governance was released in 2014. The revised code specified the duties of the directors, instituted stiff penalties for non-compliance with the code, and ensured uniformity in the reporting of financial affairs of the banking system (Ozili \& Uadiale, 2017). Since then, the issue of bank liquidations and foreclosures has significantly reduced.

Nigeria has the necessary framework to ensure a healthy banking industry. Still, inappropriate behavior and connivance between the staff of the regulatory agencies and directors of the banks frustrate full compliance with the codes of corporate governance (Omoijiade, 2016). Over 90\% of the studies in the past had focused on the operators of the banking sector in Nigeria.

The results have shown that the problems in the Nigerian banking sector arose from the fact that some banks do not fully comply with the code of corporate governance. It resulted in increased levels of irrecoverable loans. The banks also had weak capital adequacy ratios, and severe hardship to individual savers and depositors of the banks (Afolabi \& Dare, 2015; Omoijiade, 2016; Ozili \& Uiadiale, 2017)).

In order to have a balanced view, there was a need to have an in-depth understanding of the issues associated with governance, especially from the perspective of the regulators (Osemeke \& Adegbite, 2016; Ozili \& Uadiale, 2017; Umanholen, 2015). Understanding the problems associated with the Nigerian banks' inability to comply fully with the code of corporate governance from the perspective of the regulators may give a more profound understanding into how to curtail the incidence of bank failures and liquidations that are prevalent in Nigeria (Afolabi \& Dare, 2015). 


\section{Research Question}

The research question for this qualitative exploratory case study was: RQ: Does the amended code of corporate governance 2014 affect the level of compliance by Nigerian banks?

\section{Data Collection and Data Analysis Plan}

Twenty-five face-to-face interviews were conducted in the offices of the participants; the focus group interview was done in a quiet place in the premises of the CBN. The design of the interview questions ensured that the participants were not under any stress but could answer the items freely. Probes were necessary from time to time for clarity (Miles \& Huber man, 1994). Each interview session lasted for about 30 minutes while the focus group interview lasted longer, for about 45 minutes, to allow time for all members' make contributions. The data originating from the face-to-face meetings, focus group interviews, and document review was processed using the steps as suggested by (Yin, 2014). To answer the research question, the themes were collated. Then the interpretation, inferences, and recommendations followed. Because the bank regulators are busy people who rarely grant interviews, a field test was not conducted. Instead, the interview questions were scrutinized thoroughly to ensure open-endedness and nonrigidity.

\section{Results from the Research}

Thirteen emergent themes emerged from the study. These themes include comprehensive supervision, recruitment of skilled personnel, eexamination, board composition, and board meetings. Other themes include; special board committee, classification of banks, gray areas and selfregulation, penalty review and sanction power, zero shareholder influence, the omnibus clause, defined duties of board members, right of stakeholders, and internal audit report.

The two subthemes were the on-site and off-site investigation, and training and retraining. Most of the findings gave deeper insights into the current activities of the regulators. Some of the results obtained are at variance with the existing literature on the subject. Glaser and Laudel (2013) noted that a discrepant case is a data that is at variance with the perspective on the phenomenon being studied.

The findings further showed that the amended code had opened some of the loopholes and other areas where the banks render unclear reports. Besides, the leaders of the Banking and Supervision Department in the CBN have reinvigorated the assessment methods in line with the global standards. The discussions on the findings are presented hereunder: 
Table showing Triangulation of Data

Triangulation of Data from Semistructured, Focus Group, and Document Review

\begin{tabular}{|c|c|c|c|c|c|}
\hline Codes & Themes & Subthemes & $\begin{array}{l}\text { No of } \\
\text { occurrence }\end{array}$ & Data source & $\begin{array}{l}\text { Percentage of } \\
\text { occurrence }\end{array}$ \\
\hline $\begin{array}{l}\text { Carrying out both } \\
\text { on-site and off- } \\
\text { site supervision to } \\
\text { ensure that bank } \\
\text { comply with the } \\
\text { code of corporate } \\
\text { governance }\end{array}$ & $\begin{array}{l}\text { Comprehensive } \\
\text { supervision }\end{array}$ & $\begin{array}{l}\text { On-site and } \\
\text { off-site } \\
\text { investigation }\end{array}$ & 25 & $\begin{array}{l}\text { Semistructured } \\
\text { interview }\end{array}$ & $100 \%$ \\
\hline $\begin{array}{l}\text { Making } \\
\text { recruitment } \\
\text { process } \\
\text { transparent will } \\
\text { enhance the } \\
\text { recruitment of } \\
\text { skilled personnel }\end{array}$ & $\begin{array}{l}\text { Recruitment of } \\
\text { skilled personnel }\end{array}$ & $\begin{array}{l}\text { Training } \\
\text { and } \\
\text { retraining }\end{array}$ & 23 & $\begin{array}{l}\text { Semistructured } \\
\text { interview }\end{array}$ & $92 \%$ \\
\hline $\begin{array}{l}\text { Conducting } \\
\text { electronic } \\
\text { examinations for } \\
\text { banks improve the } \\
\text { on-site and off- } \\
\text { site examinations } \\
\text { for banks }\end{array}$ & E-examination & & 18 & Semistructured & $72 \%$ \\
\hline Codes & Themes & Subthemes & $\begin{array}{l}\text { No of } \\
\text { occurrence }\end{array}$ & Data source & $\begin{array}{l}\text { Percentage } \\
\text { of } \\
\text { occurrence }\end{array}$ \\
\hline $\begin{array}{l}\text { Frequency of } \\
\text { Board meeting } \\
\text { should be } \\
\text { encouraged for } \\
\text { strategic } \\
\text { discussion on the } \\
\text { code of corporate } \\
\text { governance }\end{array}$ & $\begin{array}{l}\text { Board composition } \\
\text { and board meetings }\end{array}$ & & 25 & $\begin{array}{l}\text { Semistructured } \\
\text { interview }\end{array}$ & $100 \%$ \\
\hline $\begin{array}{l}\text { Special Board } \\
\text { Committees that } \\
\text { monitors that } \\
\text { banks comply } \\
\text { with the code of } \\
\text { governance has } \\
\text { helped in the past }\end{array}$ & $\begin{array}{l}\text { Special Board } \\
\text { Committees }\end{array}$ & & 25 & $\begin{array}{l}\text { Semistructured } \\
\text { Interview }\end{array}$ & $100 \%$ \\
\hline & & & 18 & & $72 \%$ \\
\hline
\end{tabular}




\begin{tabular}{|c|c|c|c|c|c|}
\hline $\begin{array}{l}\text { All banks must } \\
\text { belong to a } \\
\text { category such as } \\
\text { low- risk, high- } \\
\text { risk average risk, } \\
\text { above average } \\
\text { risk. }\end{array}$ & Bank Classification & & & $\begin{array}{l}\text { Semistructured } \\
\text { Interview }\end{array}$ & \\
\hline $\begin{array}{l}\text { Uniform rules and } \\
\text { regulations } \\
\text { introduced by } \\
\text { CBN will provide } \\
\text { self-regulation } \\
\text { among all banks } \\
\text { in Nigeria }\end{array}$ & $\begin{array}{l}\text { Gray Area and } \\
\text { Self-Regulation }\end{array}$ & & 16 & $\begin{array}{l}\text { Semistructured } \\
\text { Interview }\end{array}$ & $64 \%$ \\
\hline Codes & Themes & Subthemes & $\begin{array}{l}\text { No of } \\
\text { occurrence }\end{array}$ & Data source & $\begin{array}{l}\text { Percentage } \\
\text { of }\end{array}$ \\
\hline $\begin{array}{l}\text { The penalties for } \\
\text { noncompliance } \\
\text { with the code of } \\
\text { corporate } \\
\text { governance rule } \\
\text { should be } \\
\text { reviewed }\end{array}$ & Penalty Review & Sanctions & 17 & $\begin{array}{l}\text { Semistructured } \\
\text { Interview }\end{array}$ & $\begin{array}{l}\text { occurrence } \\
68 \%\end{array}$ \\
\hline $\begin{array}{l}\text { No shareholder } \\
\text { should have } \\
\text { majority votes or } \\
\text { influence to } \\
\text { determine the } \\
\text { decisions made in } \\
\text { the bank. }\end{array}$ & $\begin{array}{l}\text { Zero Shareholder } \\
\text { Influence }\end{array}$ & & 25 & $\begin{array}{l}\text { Semistructured } \\
\text { Interview }\end{array}$ & $100 \%$ \\
\hline $\begin{array}{l}\text { The omnibus } \\
\text { clause is in } \\
\text { subsection } 60 \text { of } \\
\text { BOFIA as } \\
\text { amended }\end{array}$ & Omnibus Clause & & 16 & $\begin{array}{l}\text { Semistructured } \\
\text { Interview }\end{array}$ & $64 \%$ \\
\hline $\begin{array}{l}\text { Defining the } \\
\text { duties of every } \\
\text { board member } \\
\text { provide clarity to } \\
\text { board members to } \\
\text { know what is } \\
\text { required for } \\
\text { compliance with }\end{array}$ & $\begin{array}{l}\text { Defined Duties of } \\
\text { the Board } \\
\text { Members }\end{array}$ & & 5 & Focus Group & $100 \%$ \\
\hline
\end{tabular}




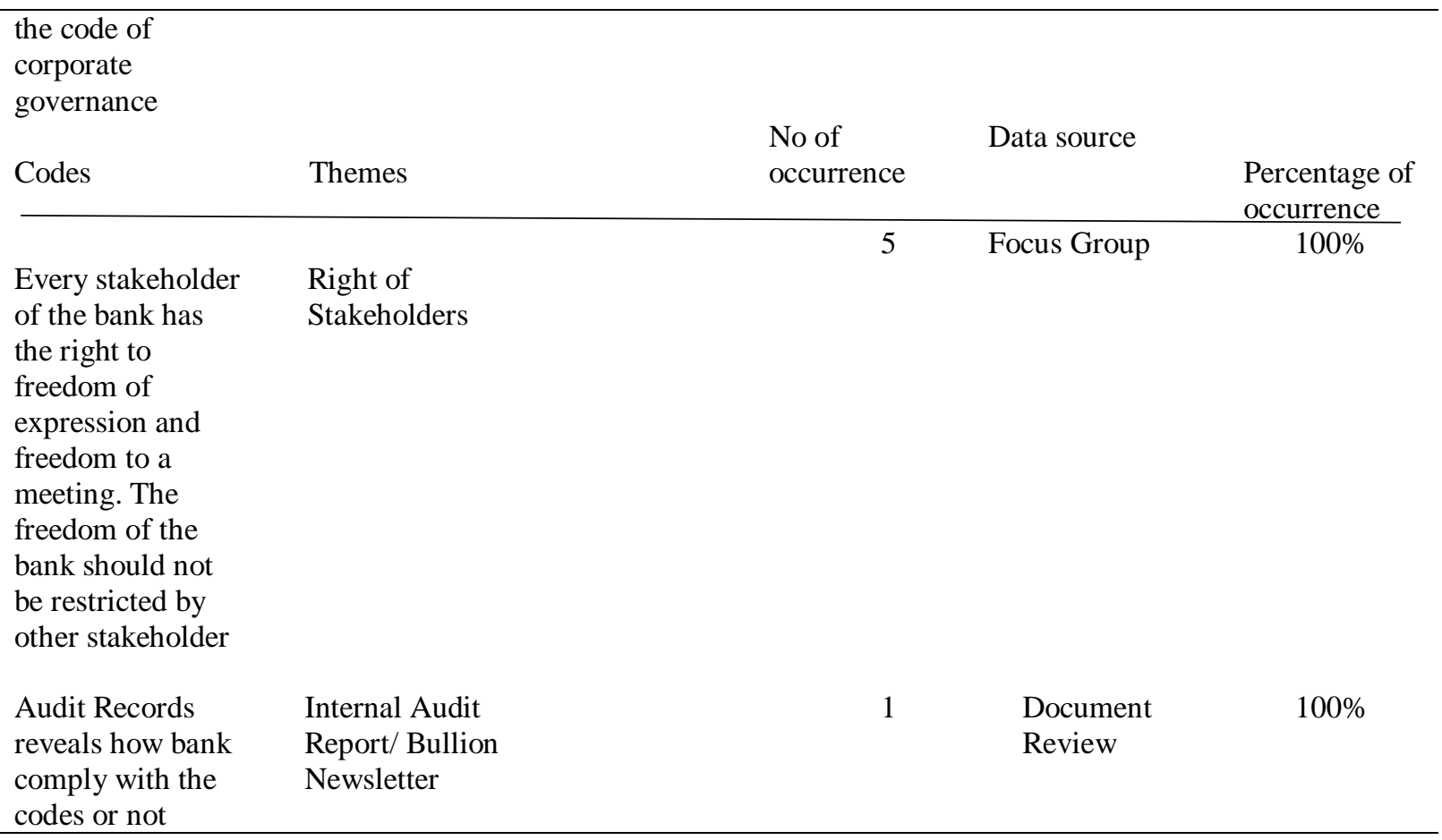

\section{Comprehensive Supervision}

Under the amended code, an annual comprehensive examination of the Bank and the subsidiaries is imperative. In the past, the weak financial position of some banks subsidiaries had negatively influenced the books of the parent bank. The situation had occurred in the past, whereby the adverse financial accounts of subsidiaries of some banks negatively affected the holding companies (Umaholen, 2015). The CBN now performs comprehensive examinations to confirm the soundness of banks' subsidiaries so that unexpected shocks from them do not ultimately lead to the collapse of the holding banks.

\section{Training and Retraining}

To ensure that the staff members imbibe global best practices, the CBN had intensified staff training. In-depth training is conducted on an on-going basis from time to time, both locally and offshore. The regulators now write examinations regularly, and only those that excelled in the studies remain in the department. The focus group interview further revealed that prior challenges of the incompetent workforce are being corrected through on-going extensive staff training 


\section{On and Offsite Examination}

In line with the need for a thorough examination as stipulated in the amended code, the CBN now carries out an in-depth monthly analysis of the books of the banks. It would appear that the situation not so in the past. A detailed inspection of banks was done only once in a year. The monthly examination, called the off-site examination, is conducted when the banks download their returns to the central server of the CBN monthly. The IT Department of the $\mathrm{CBN}$ is now linked directly to the servers of the Nigerian banks so that live data are transmitted by the banks monthly, leaving no room for manipulation. The on-site examinations are examinations conducted on the premises of the banks (Omoijiade, 2016). On-site inspections are usually undertaken annually in the past. However, they are now held quarterly or semiannually depending on the classification of the Bank and if there is the need for an impromptu physical inspection of the books of the Bank.

In the past, it appeared that banks keep two sets of accounts: the exact statements, which showed the precise position of the Bank, and another report, with falsified financials, for the auditors and the regulators (Umanholen, 2015). It is therefore not surprising that a bank may suddenly be unable to meet its obligations only a short time after the regulators had conducted a routine examination and judged the Bank to be healthy (Osemeke \& Adegbite, 2016).

As demonstrated in this paper, the recent introduction of eexamination, or technology-based inspections, had curbed the deceptive practices used by banks. According to Leeming (2018), the use of technology in the banking industry has transformed and enhanced delivery channels and opened up new areas for users to conveniently access financial information.

In addition, responses obtained revealed that the past problems associated with obtaining the correct financial positions of the banks from the balance sheet and the profit and loss positions have been resolved. The CBN does not have fictitious accounts any longer. The issues of late accounts submission have also been addressed. This is because the server of the CBN directly interfaces with the servers of all licensed banks in the country so there is no room for manipulation of accounts as may have been the case in the past. No doubt, this is a major achievement of the revised code.

\section{Recruitment of IT Personnel}

The CBN has recruited a large number of IT professionals, and they have been invaluable in providing a quick review of the monthly returns sent in by the banks. Since the servers of all the licensed banks are linked directly to the $\mathrm{CBN}$, the system highlights observed discrepancies monthly, and regulators call for timely reconciliation before the situation deteriorates, failing which the affected Bank may be sanctioned. It must be noted that the 
CBN had always conducted e-examinations of banks. Still, it may not have been as rigorous and in-depth as it is done currently because of the modern sophistication of the IT department.

The participants' constant use of phrases like "that was in the past; it cannot happen again" points to the fact that the situation may have occurred in the past, but the era has passed, and the issue of rendering undetected fictitious accounts cannot happen again. Umanholen (2015) observed that in the past, regulators performed the annual comprehensive inspections of banks. Conducting the infrequent checks may have created room for the malpractices on the part of the banks (Ozili \& Uadiale, 2017).

\section{Board Composition, Tenure and Board Meetings}

Under the amended code, the CBN has given directives to all banks on how often they are to conduct board meetings. The regulators also now review the minutes of the sessions to ensure compliance. In the past, banks hold the board meetings at the discretion of the chairperson or the managing director. Then, some bank owners and chief executive officers made their associates or family members directors. These directors would not challenge the actions taken by the banks (Ozili \& Uadiale, 2017).

As argued here, some aspects of the amended code had curtailed the overbearing influences of the directors and chairpersons of banks. The impunity on the part of bank directors and chairpersons contributed to past bank failures (Achim, Borlea, \& Mare, 2016). The amended corporate governance code stipulated the maximum tenor for the directors on the boards of banks.

A director could not spend more than three terms, or twelve years, on the board of any bank. The CEOs of the banks also have a shorter tenure of no more than ten years. In the past, the owners of banks stay on the board of banks for as long as possible. The stipulations of the amended code have now put an end to this. Again, this is a major achievement by the CBN. The code made a distinction between the position of board chairperson and managing director (CEO) such that no single individual can double as the CEO and chairperson, as was the case in the past.

\section{Creation of Special Board Committees}

The nature of special board committees has been of tremendous help to the banks, and it has simplified the on-site examination processes for the regulators. Some banks failed in the past because of illiquidity. The situation arose because they carried a large number of a sticky and irrecoverable riskasset portfolio (Omojiade, 2016).

After the global economic crisis of 2008, many Nigerian banks became distressed (Afolabi \& Dare, 2015), because most of them did not have the 
internal mechanisms to ensure booking of high-quality credits (Saeid \& Sakine, 2015). To forestall the steady deterioration of banks' assets and avert future Bank distresses, the amended law of corporate governance provided for the creation of two essential board committees in the Bank, which ensure that the banks the review risk portfolio and financial position of the banks continuously.

These are the risk-asset and audit committees. The introduction of the committees has been of tremendous help in curtailing the excesses of the bank directors. The audit committee is statutory because the banks' auditors make use of this committee's report to audit the banks and prepare the yearlypublished accounts. Financial reporting is one significant indicator of an organization's accountability and transparency (Lau, Lu \& Liang, 2016). The Credit committee ensures that the assets do not deteriorate to influence the profits of the banks negatively.

The boards of banks now have a reasonable number of independent directors. Proponents of agency theory argue for a significant number of external and independent directors on the board of organizations to ensure thorough scrutiny of the books of the banks (Ozili \& Uadiale, 2017). The independent directors also bring a wealth of experience to the banks (Twining; Heller; Nussbaum \& Tsai 2017).

\section{Classification of Banks}

Unknown to the public, the CBN uses some parameters to classify the inherent risk of each Bank's portfolio. The CBN classifies the banks under four categories, namely, low-risk, high-risk, above average-risk, and moderaterisk. Banks in the high-risk group are under the watchful eyes of the regulators, they do not have strong financials, and the shareholders' funds are almost eroded.

The CBN recently changed the entire board and management of one of the banks in the high-risk group because the collapse of the Bank was imminent, and the shareholders could not inject additional funds to stabilize it. Banks classified under the above-average risk are also weak banks with weak financials, which are, however, slightly better than the high-risk banks. Moderate-risk banks are banks with sound financials and with a good credit portfolio.

The best group is the low-risk group because the books of the banks in this category are well- managed and the financials are strong. Banks in the low-risk group are reliable, efficient, and they comply fully with the code of corporate governance. With the classification of the banks, the examiners' job is somewhat simplified because they can now devote more attention to the banks in the high-risk category. As a result, the $\mathrm{CBN}$ can quickly offer 
intervention measures to salvage the situation and forestall public outcry to such banks.

\section{Gray Areas and Self-Regulation}

Findings revealed that the regulators had addressed the possible gray areas that the banks manipulated in the past. The respondents emphasized that there are no longer any lapses or gray areas on the regulatory examination of the banks by the CBN. The banks are now under intensive scrutiny by the regulators, and the directors do not want to tarnish their names. Accordingly, the banks have now imbibed self-regulatory measures in their activities.

The CBN had recruited IT professionals who always scrutinize the books of the banks. They have been able to close all loopholes that the banks maneuver in the past. As demonstrated here, the amended code is explicit, detailed, and unambiguous so that the requirements from all parties are precise.

\section{Penalty Review and Sanction Power}

The enforcement of stringent penalties for non-compliance by the banks led to the sacking of bank directors lately. In the past, the penalties stipulated for non-compliance were too meager. The banks preferred to pay the penalties instead of complying with the code. Under the amended system, the sanctions have been reviewed upwards significantly, such that any payment of fine could have a substantial negative impact on the balance sheet of the Bank.

\section{Zero Shareholder Influence}

Findings revealed that the shareholders of the banks are not involved in the examination process and that they are not around when the regulators go in for routine inspections. The shareholders only attend the banks' annual general meetings after the $\mathrm{CBN}$ has approved their financial accounts. Under subsection 81 of CAMA, the shareholders of banks have the right to attend the annual general meetings to vote and ask the directors questions.

Furthermore, the shareholders have rights to the banks' profits, as well as to inspect the registers of the banks' members. Under the amended code, no shareholder should have more than 5 percent equity in any bank, and, therefore, none of them has a controlling voice over the affairs of the Bank.

\section{Use of the Omnibus Clause}

The $\mathrm{CBN}$ Governor can rely on the omnibus clause contained in the amended code to issue out more stringent penalties to erring banks as the situation demand. Recently a bank paid over N200m because of this. The CBN governor now uses the omnibus clause to increase the applicable sanctions to 
the banks whenever appropriate. The $\mathrm{CBN}$ governors did not apply the omnibus clause extensively used in the past. Because of the competition for dominance in the marketplace, banks do not want to do anything that might negatively affect their profits or their reputation, and they, therefore, make efforts to ensure compliance with the code of corporate governance.

\section{Recruitment of Staff from Commercial Banks}

Scholars argue that there may be gray areas in the code that the banks manipulate to suit their purposes (Afolabi \& Dare, 2015; Umanholen, 2015). The results of this investigation confirmed this assertion. To mitigate this, the $\mathrm{CBN}$ had recruited staff from commercial banks that now assist in the regulatory activities by closing loopholes that could be exploited. Additionally, the past and current $\mathrm{CBN}$ governors are both former employees of commercial banks, and they have first-hand knowledge of the possible shortcomings of earlier code.

\section{Internal Audit Report}

The theme internal audit report emerged from the audit report document reviewed at the $\mathrm{CBN}$ during the data collection process. From the materials studied, it showed that $\mathrm{CBN}$ had included in the regulatory framework of the banks, an internal control system that would facilitate compliance with the code of corporate governance. Qussii and Taktak (2018) inferred that the presence of an audit system in the Bank is a measure of agreement with the rules and regulations set by the CBN.

In summary, this research has revealed that the $\mathrm{CBN}$, through the amended code of corporate governance, has put lasting measures in place to forestall future occurrences of bank failures in Nigeria.

\section{Potential Impact of this Research Implications for Practice}

The research findings have the potential contribution to the existing literature on the subject to shed more insight at the CBN's efforts in getting Nigerian banks to comply with the corporate code of governance and, in turn, to curb the incessant bank failures in Nigeria. A significant number of existing works of literature on the subject still shows that most of the Nigerian banks are not complying with the code of corporate governance because of regulatory ineptitude (Afolabi \& Dare, 2015; \& Osemke \& Adegbite, 2016; Renz, Renz, Carrington \&Terry, 2018; Umanholen, 2015). The findings show that many of the banks are now compliant since the $\mathrm{CBN}$ has put measures in place to ensure compliance.

The research revealed that regulators have now tried to mitigate previous issues that contributed to bank failures, and that they are now well 
prepared to curb the excesses of the Nigerian banks and forestall future bank foreclosures and liquidations. The study may assist the Federal Government of Nigeria and its policymakers in enacting laws that will make violations of the code of corporate governance punishable under the law (Nwagbara \& Ugorji, 2015).

\section{Implications for Theory}

Leeming (2018) argued that, in line with agency theory, managers are expected to work in the best interests of the stakeholders. Bank managers carry out their duties efficiently to generate profit for the stakeholders, as mandated by law, and bank regulators ensure that the banks comply with all the requirements to provide stability in the banking sector. As demonstrated in this paper, the regulators have put mechanisms in place to ensure that the banks comply fully with the code of corporate governance, which, in turn, ensures that the banks operate smoothly and profitably to accommodate all stakeholders. To provide additional protection of the shareholders' funds, the $\mathrm{CBN}$ has directed the creation of the audit and credit committees to monitor the loan portfolios and profitability of the banks at all times.

\section{Implications for Positive Social Change}

Corporate governance enhances the financial performance of banks to provide a favorable financial standing that promotes economic growth (John \& Obokoh, 2018). A viable banking sector fosters investors' confidence (Agyemang \& Castellini, 2015). An efficient financial system encourages savings and deepens financial intermediation, which in turn creates increased domestic capital and investment activities (Leeming, 2018). There will resultantly be increased employment opportunities for the population (Agyemang, \& Castellini, 2015), and bank failures and attendant staff retrenchments will be drastically reduced (Lau, Lu \& Liang, 2016).

As argued in this paper, the compliance level of Nigerian banks may have improved after the 2009 global crisis because of the various measures put in place by the CBN.

Accordingly, the regulators firmly believe that the issues of a bank foreclosure and liquidation will not often occur in Nigeria. Therefore, the problem of staff reduction and layoffs with the attendant adverse effect on families and domestic activities will reduce. In general, the confidence of the Nigerian banking public in the sector will improve, leading to growth in savings activities and other developmental projects in the nation.

\section{Conclusion}

The purpose of this qualitative, exploratory case study was to access the effect of the amended code of corporate governance 2014 on the level of 
compliance of Nigerian banks while exploring the challenges confronting the $\mathrm{CBN}$ leaders in this regard. Findings confirmed that although the regulators in the past regularly supervised the banks, the monitoring might not have been comprehensive enough to detect problems in all the departments of the banks.

The CBN has significantly improved the bank examination process and has implemented several measures that will ensure that the banks fully comply. In addition to the on-site examination, the regulators now rigorously monitor the bank monthly through the off-site supervision that allows for the collection of data from the servers of banks, leaving no room for no possibility of record falsification as was rampant in the past. There has been the massive recruitment of professionals, particularly IT experts, who examine the banks' returns and call for immediate reconciliation when discrepancies are noticed. The CBN has also gone ahead and recruited staff from commercial banks that have brought in their experiences to further boost the examination processes.

In the past, the penalties for an infraction of the code of corporate governance are soft, and the banks can pay without difficulty and continue to circumvent the code (Ekhator \& Anyiwe, 2016). However, the CBN governor now relies on an omnibus clause in the code that allows for severe sanctions on the banks for any infraction.

As the banker of last resort, the $\mathrm{CBN}$ is set to regain the public trust in the Nigerian banking sector. Rather than allow a bank to become distressed, the regulators would pump in additional funds and change the bank's management and board. To date, 2 banks boards have been affected. The era when a single individual would own the controlling interest in a bank is over. In line with the code, no single individual can own more than five percent of the paid-up capital of any bank. Directors of the banks are also under the watchful eyes of the regulators and held accountable for any problems within the banks. The CBN continually trains the staff to adapt to constant changes and challenges in the marketplace.

Continuous and effective monitoring of the measures put in place will adequately ensure that the banks comply fully with the code. If the CBN succeeds, then the problems encountered by the regulators will have been mitigated, and the era of bank failures in Nigeria will be outdated.

\section{References:}

1. Achim, M. V., Borlea, S., \& Mare, C. (2016). Corporate governance and business performance: Evidence for the Romanian economy. Journal of Business Economics and Management, 17(3), 458-474. doi:10.3846/16111699.2013.834841

2. Afolabi, A., \& Dare, A. (2015). Corporate governance in the Nigerian banking sector: Issues and challenges. European Journal of 
Accounting, Auditing, and Finance Research, 3(55), 64-89. Retrieved from http://www.eajournals.org

3. Agyemang, O. S., \& Castellini, M. (2015). Corporate governance in an emergent economy: A case of Ghana. Corporate Governance: The International Journal of Business in Society, 15, 7-44. doi:10.1108/CG-04-2013-0051

4. Glaser, J., \& Laudel, G. (2013). Life with and without coding: Two methods for early-stage data analysis in qualitative research aiming at causal explanations. Forum: Qualitative Social Research, 14(2), 1-37. Retrieved from http://www.qualitative-research.net/

5. Lau, C., Lu, Y. \& Liang, Q (2016). Corporate Social Responsibility in China: A corporate governance approach. JBus Ethics 136, 7687.doi:10.1007/s10551-014-2513-0.

6. Leeming, D. (2018).The use of theory in qualitative research. Journal of Human Lactation, 34(4), 668-673. http: //doi.org /10.1177/0890334418794666

7. Miles, M. B., \& Huberman, A.M. (1994). Qualitative data analysis: An expanded sourcebook. Thousand Oaks, CA: Sage Publications

8. Omoijiade, P.0. (2016). Historical Analysis as a diagnostic tool of orporate governance ailment in the Nigerian Banking sector. Journal of Finance and Bank Management, 4, (1)112124.doi:10.15640/jfbm.v4n1a8

9. Osemeke, L. \& Adegbite, E. (2016). Regulatory multiplicity and conflicts: towards a combined code on corporate governance in Nigeria. Journal of Business Ethics, 133, 431451.doi.10.1007/s/10551-014-2405-3

10. Ozili, P.\& Uadiale,O. (2017). Ownership concentration and bank profitability. Future Business Journal 3(2)159171.https://doi.org/10.1016/j.fbj.2017.07.001

11. Nwagbara, U. \& Ugworji, C. (2015). Corporate governance, CSR reporting, and accountability: The case of Nigeria. Economic InsightsTrends and Challenges, 4(1), 77-84. Retrieved from http://www.upgbulletin-se.ro/archive/2015-1/9.Nwagbara_Ugwoji

12. Renz, S., Renz, J., Carrington, M., \& Terry, A. (2018). Two strategies to qualitative content analysis: An intramethod Approach to Triangulation. Qualitative Health Research, 28(5), 824-831. https://doi.org/10.1177/1049732317753586

13. Qussii, A. A., \& Taktak, N. B. (2018). Audit report timeliness. Does internal audit function coordination with external auditors' matter? Empirical evidence from Tunisia. EuroMed Journal of Business, 13, 60-74. doi:10.1108/EMJB-10-2016-0026 
14. Twining, P., Heller, R., Nussbaum, M.\& Tsai, C.(2017). Some guidance on conducting and reporting qualitative studies. Computers $\&$ Education, 106 , A1-A9. https://doc.org/10.1016/j.compedu.2016.12.002

15. Umanholen, O. (2015). Effect of the global financial meltdown on the Nigerian banking industry and economy. Scientific \& Academic Publishing, 5(3), 63-89. doi:10.5923/j.mm20150503.01

16. Yin, R. K. (2014). Case study research: Design and methods (5th ed.). Thousand Oaks, CA: Sage Publications 